\title{
An Extended Dual-Process Model of Entertainment Effects on Political Information
}

\section{Processing and Engagement}

This is a draft of a chapter that has been accepted for publication by Oxford University Press in the forthcoming book The Oxford Handbook of Entertainment Theory edited by Peter Vorderer \& Christoph Klimmt due for publication in 2020.

Frank M. Schneider, University of Mannheim

Anne Bartsch, University of Leipzig

Larissa Leonhard, University of Leipzig

Author Note

Correspondence concerning this paper should be addressed to Frank M. Schneider, Institute of Media and Communication Studies, University of Mannheim, B 6, 30-32, 68159 Mannheim, Germany. E-mail: frank.schneider@uni-mannheim.de, Phone: +49 621 1813938, Fax: +49621 181-3939. 


\begin{abstract}
This chapter reviews the controversial relationship of entertainment and political communication and presents a theoretical framework to integrate seemingly contradicting concepts and research findings. On the one hand, concerns have been raised about the decay of news quality and political culture due to the growing influence of entertainment media. On the other, researchers have highlighted the potential of entertainment in terms of audience interest, cognitive accessibility, and public outreach. A literature overview shows theoretical and empirical support for both sides of the controversy about the (dys-)functionality of entertainment in political communication. Therefore, in an attempt to reconcile the divergent findings, the chapter presents an extended dual-process model of entertainment effects on political information processing and engagement. This framework offers substantial extensions to existing dual-process models of entertainment by conceptualizing the effects of entertainment on different forms of political engagement that have not been incorporated so far.
\end{abstract}

Keywords: eudaimonic and hedonic entertainment; motivated cognition; political information processing; political; political entertainment engagement 


\section{Entertainment and Political Communication-A Controversial Relationship}

With declining circulation numbers of traditional news media such as newspapers, and a simultaneous proliferation of entertainment media and hybrid formats such as infotainment and reality TV, concerns have been raised about the decay of news quality and political culture. For example, Postman (1986) famously argued that we are "amusing ourselves to death" due to the growing influence of entertainment media, and their successive merger with the news media. In this context, trends towards tabloidization and sensationalism have been observed in both press and broadcast journalism, including phenomena such as personalization, visualization, and emotionalization of political news content (e.g., Brants \& Neijens, 1998; Donsbach \& Büttner, 2005; Esser, 1999; Otto, Glogger, \& Boukes, 2017; Reinemann, Stanyer, Scherr, \& Legnante, 2012; Sparks \& Tulloch, 2000). The concept of soft news (Reinemann et al., 2012) defines this pattern of entertainment-related news features as follows: "The more a news item is not politically relevant, the more it reports in an episodic way, focuses on individual consequences of events, is personal and emotional in style, the more it can be regarded as soft news."

The trend toward soft news and toward convergence of information and entertainment media is rather uncontroversial among communication scholars. However, the normative implications of such a convergence are a matter of ongoing debate (e.g., Andersen, 2019; Baum, 2005; Friedrich \& Jandura, 2012; Otto et al., 2017; Roth, Weinmann, Schneider, Hopp, \& Vorderer, 2014; Umbricht \& Esser, 2016; Weinmann \& Vorderer, 2018). Can entertaining forms of political communication be useful to reach audience groups who are less interested in politics? Or do they undermine audiences' trust in politics and distract them from serious consideration of political issues? Theoretical and empirical evidence seems to support both claims. On the one hand, soft news and sensationalism have been described as cause of disillusionment with politics and decreasing civic engagement (Esser, 1999; 
Guggenheim, Kwak, \& Campbell, 2011; Putnam, 2000). Some studies found "very limited evidence that viewers actually learn from soft news" (Prior, 2003, p. 149), and an association of soft news consumption with political cynicism (Boukes \& Boomgaarden, 2015). Especially the latter finding challenges the conduciveness of soft news in terms of the democratic ideal of informed and engaged citizens, as political cynicism can demobilize citizens and foster political apathy (Valentino, Beckmann, \& Buhr, 2001). On the other hand, it has been argued that individuals' emotional involvement with entertaining news formats can help establish at least basic forms of political knowledge and issue awareness among audience groups who are less interested in politics (e.g., Andersen, 2019; Baum, 2003). Indeed, there is evidence that soft news can provide an "entrance to the political arena for the uninterested" (Andersen, 2019, p. 16) by encouraging passive forms of political participation such as further information seeking. Soft news can even have an impact on voting behavior of politically inattentive citizens by providing them with the necessary information to make their voting decision according to their interests (Baum \& Jamison, 2006). Moreover, some recent findings suggest that under certain conditions entertainment media can stimulate more elaborate forms of information processing (Bartsch, Kalch, \& Oliver, 2014; KnoblochWesterwick, Gong, Hagner, \& Kerbeykian, 2012; LaMarre, 2009), and can stimulate audience interest in hard news about the topic (Bartsch \& Schneider, 2014). In the present chapter, we aim to revisit and integrate these seemingly contradictory concepts and research findings concerning audiences' processing of entertaining forms of political communication and associated effects.

Most of the research on the processing and effects of political information in the context of entertainment has focused on superficial and unreflective learning and persuasion effects. For example, theories of cultivation (Gerbner, Gross, Morgan, Signorielli, \& Shanahan, 2002), narrative persuasion (Green \& Brock, 2000), and fictional priming 
(Holbert et al., 2003) concur that entertainment fosters a heuristic mode of cognitive processing in which information, attitudes, and stereotypes portrayed in the media are assimilated into individuals' worldview without critical reflection.

This heuristic mode of information processing and its outcomes are relatively well researched in the context of entertainment media, however, it does not cover the whole range of affective and cognitive processing (Forgas, 1995). Recent advances in entertainment theory have drawn attention to the multidimensionality of entertainment experiences (e.g., Oliver \& Bartsch, 2010; Oliver \& Raney, 2011; Schramm \& Wirth, 2008; Tamborini, Bowman, Eden, Grizzard, \& Organ, 2010; Vorderer \& Reinecke, 2012; Vorderer \& Ritterfeld, 2009; Wirth, Hofer, \& Schramm, 2012; see also Bryant, Klimmt \& Vorderer; Tamborini [Chap. 3]; Janicke-Bowles, Bartsch, Oliver \& Raney in this volume). In particular, scholars have argued that besides superficial, heuristic processing, entertainment experiences can also stimulate a more elaborated, systematic mode of processing (Bartsch \& Schneider, 2014; Klimmt, 2011; Lewis, Tamborini, \& Weber, 2014; Oliver \& Raney, 2011; Vorderer \& Reinecke, 2012; Wirth et al., 2012). Such entertainment experiences associated with elaborate, deliberative processing bear particular promise for normatively desirable outcomes such as further information seeking, active knowledge acquisition and political participation.

Therefore, in the remainder of this chapter, we aim to develop an integrated framework that covers both superficial, heuristic processing and more elaborate, deliberative responses to political information in entertainment media. We build on the dual-process model of entertainment experience and motivated cognition (Bartsch \& Schneider, 2014) that integrates entertainment theory with dual-process models of information processing (e.g., Forgas, 2002; Lang, 2006; Petty \& Cacioppo, 1986). In the current chapter, theoretical integration will be taken one step further by incorporating different types of politically 
relevant outcome variables such as knowledge acquisition, opinion formation, changes in attitudes and behavior as well as political participation.

\section{Connecting Entertainment Experiences with Heuristic and Elaborate Processing}

The dual-process model of entertainment experience and motivated cognition (Bartsch \& Schneider, 2014) builds on recent frameworks in entertainment theory (e.g., Oliver \& Bartsch, 2010; Oliver \& Raney, 2011; Schramm \& Wirth, 2008; Tamborini et al., 2010; Vorderer, Klimmt, \& Ritterfeld, 2004; Vorderer \& Reinecke, 2012; Wirth et al., 2012) that distinguish between hedonic and eudaimonic entertainment experiences. As explained below, these different types of entertainment experiences can be linked to different modes of information processing and different types of politically relevant outcomes.

Theories of hedonic and eudaimonic entertainment experiences (e.g., Oliver \& Bartsch, 2010; Oliver \& Raney, 2011; Schramm \& Wirth, 2008; Tamborini et al., 2010; Vorderer et al., 2004; Vorderer \& Reinecke, 2012; Wirth et al., 2012) differentiate between two types of media experiences that can be entertaining, in the sense that they attract audience interest independent of other goals and incentives than the viewing experience itself. On the one hand, entertainment consumption can be intrinsically appealing because it makes individuals feel better immediately in terms of regulating mood and arousal. This process of affect regulation through media use is thought to be the core of hedonic motivation for entertainment consumption (Knobloch-Westerwick, 2006; Zillmann, 1988). On the other hand, entertainment consumption can also serve to stimulate rewarding social and cognitive experiences that contribute to emotional well-being in more complex and sustainable ways; for example, they may foster a sense of cognitive challenge, truth-seeking, or search for meaning in life (e.g., Bartsch, 2012a; Bartsch \& Hartmann, 2017; Oliver \& Raney, 2011; Oliver et al., 2018; Schramm \& Wirth, 2008; Tamborini et al., 2010; Vorderer et al., 2004; Vorderer \& Reinecke, 2012; Wirth et al., 2012). On the basis of the distinction in ancient 
philosophy between hedonic and eudaimonic happiness (i.e., happiness derived from pleasure vs. happiness derived from meaning and insight; cf. Aristotle, trans. 2002), this second type of entertainment motivations has been labeled eudaimonic motivation (Oliver \& Raney, 2011; Wirth et al., 2012). In the following paragraph, we explain how these two types of entertainment experiences are theoretically linked with dual-process models of motivated information processing (Chen \& Chaiken, 1999; Forgas, 2002; Kahneman, 2003; Lang, 2006; Petty \& Cacioppo, 1986).

\section{Hedonic Entertainment and Motivated Cognition}

The hedonic side of entertainment has mainly been studied in the context of mood management theory (Knobloch-Westerwick, 2006; Zillmann, 1988). According to Zillmann (1988), four characteristics of media content are essential for hedonic mood regulation: (a) a positive hedonic valence, (b) the excitatory potential that can help to regulate aversive states of stress or boredom by inducing a pleasant state of moderate arousal, (c) the absorption potential of the media content that can help distract individuals from negative thoughts, and (d) the lack of semantic affinity of the media content with the eliciting situation of current negative moods. Three of these mood management factors, hedonic valence, absorption potential, and lack of semantic affinity, are theoretically linked to heuristic information processing.

Hedonic valence. According to the affect-as-information model (Schwarz \& Clore, 2003), positive mood signals to the organism that “everything's fine.” Consequently, a casual, effortless mode of information processing is sufficient (e.g., Lang, 2006).

High absorption potential. The limited capacity model of motivated mediated message processing (LC4MP; Lang, 2006) assumes that individuals' capacity for information processing is limited. If attentional resources are fully absorbed in processing a given stimulus, no further resources are available for processing additional content. Thus, 
absorption of cognitive resources interferes with critical elaboration of the media message (e.g., Green \& Brock, 2002; Moyer-Gusé, 2008; Slater \& Rouner, 2002).

Lack of semantic affinity. Entertainment content that is far removed from everyday concerns offers little semantic affinity with individuals' negative moods. At the same time, however, such a lack of semantic affinity goes along with low personal relevance-which is a key factor in message elaboration (e.g., in the elaboration likelihood model, ELM; Petty \& Cacioppo, 1986).

Moderate excitatory potential. The only mood management factor that seems compatible with elaborate information processing is moderate arousal. According to the LC4MP (Lang, 2006), states of low to moderate arousal are physiologically associated with attentive and motivated processing, whereas high arousal interferes with elaborate processing. Thus, a moderate state of excitement should not only improve individuals' mood but should also optimize the balance of message attention and message elaboration. However, in the context of other mood management factors, including highly suspenseful, absorbing stories, positive valence, and lack of semantic affinity to real world concerns, it remains unclear whether the cognitively stimulating effects of moderate arousal alone could lead to a deeper involvement with political issues.

From a mood management perspective, thoughts about the self or reality that go beyond the (fictional) content of entertainment media would undermine the mood regulation function of entertainment and should therefore be avoided. Thus, in the case of hedonic entertainment, the long-standing skepticism about the escapist nature of entertainment seems principally justified. Nevertheless, political entertainment content can exert its influence on media users via heuristic processing such as associative learning or availability heuristics that have been extensively studied in research on cultivation (Gerbner et al., 2002; Shrum, 2002), exemplification (Zillmann \& Brosius, 2000), narrative persuasion (Appel, 2008; Green 
\& Brock, 2000) as well as fictional framing, priming, and agenda setting (Holbert et al., 2003; Holbrook \& Hill, 2005; Mulligan \& Habel, 2011).

Comparatively little attention has been paid to elaborate processing of politically and socially relevant topics in the entertainment context so far. As explained in the next section, the concept of eudaimonic entertainment provides an interesting complementary approach that allows to integrate deliberate and elaborate processing of political information in an entertainment context.

\section{Eudaimonic Entertainment and Motivated Cognition}

Compared to escapist, hedonic motivations, the eudaimonic entertainment experience is characterized by more serious motivations such as the search for meaning, truth and selfdevelopment. Such eudaimonic goals often require a confrontation with negative thoughts and feelings, and can motivate individuals to turn to serious and potentially unpleasant media content that they would rather avoid for purely hedonic reasons. Various studies have shown that eudaimonic gratifications play a key role in entertainment consumption, even though they are often associated with negative emotions such as fear, anger, and sadness (Bartsch, 2012b; Oliver \& Bartsch, 2010; Oliver \& Raney, 2011; Wirth et al., 2012). Further, in contrast with the escapist nature of hedonic entertainment experiences that can provide audiences with a "brain holiday" from everyday concerns, eudaimonic entertainment experiences tend to focus on realistic and socially relevant topics (Cupchik, 1995; Oliver \& Hartmann, 2010) and are typically associated with a slower narrative pace (Cupchik, 1995; Cupchik \& Laszlo, 1994). The theoretical relationship of these characteristics of eudaimonic entertainment experiences with motivated information processing is mostly opposite to the escapist nature of hedonic entertainment experiences as described above.

Negative valence and mixed affect. According to the affect-as-information model (Schwarz \& Clore, 2003), negative mood alerts the organism that "something may be wrong" 
and the situation needs to be carefully examined, especially if important concerns are at stake. Consequently, thorough information processing is required (e.g., Lang, 2006). Moreover, eudaimonic entertainment is often characterized by mixed (negative and positive) affect (Oliver, 2008), which can further intensify the elaboration effects of negative valence, due to a coactivation of appetitive and aversive motivational systems (Cacioppo, Gardner, \& Berntson, 1999; Lang, Sanders-Jackson, Wang, \& Rubenking, 2013).

Low absorption potential. Eudaimonic entertainment is also characterized by a slower narrative pace with correspondingly low absorption potential (e.g., Cupchik \& Laszlo, 1994). According to the LC4MP (Lang, 2006), less absorption of attention means that more cognitive resources are available for elaborate processing.

Personal relevance. The "truth-seeking" focus of eudaimonic motivation (Oliver \& Raney, 2011) involves a preference for realistic and personally relevant content, which should increase individuals' sense of personal involvement and their elaboration likelihood, according to the ELM (Petty \& Cacioppo, 1986).

Excitatory potential. The only motivational factor that hedonic and eudaimonic entertainment seem to share in common is moderate arousal (Bartsch, 2012b; Bartsch \& Oliver, 2011). As explained above, with regard to hedonic entertainment, a moderate level of arousal seems optimal in terms of stimulating cognitive elaboration, according to the LC4MP (Lang, 2006). Thus, moderate arousal is beneficial for a deeper information processing.

Taken together, eudaimonic entertainment is characterized by a set of content characteristics and experiential factors that seem to encourage cognitive elaboration, according to the research literature on motivated information processing, including negative or mixed affect, moderate arousal, low absorption of attention, and semantic affinity with personally relevant concerns. In contrast to hedonic entertainment, serious thoughts about the self and reality do not interfere with eudaimonic entertainment experiences. Rather, cognitive 
elaboration seems to be an essential constituent of eudaimonic truth- and meaning-seeking. Preliminary research evidence supports this connection between perceived realism, eudaimonic entertainment experience, cognitive elaboration and political interest (Bartsch, Kalch, \& Oliver, 2014; Bartsch \& Schneider, 2014; Schneider, 2012).

By linking hedonic and eudaimonic forms of entertainment experiences with different modes of information processing, the dual-process model of entertainment experience and motivated cognition (Bartsch \& Schneider, 2014) provides a new and differentiated perspective on the controversial relationship between entertainment and political communication. In the case of hedonic entertainment, media consumption is driven by escapist mood-managing motivations that are associated with a superficial, heuristic mode of information processing. Thus, whereas hedonic entertainment may attract audience interest, concerns that such entertainment experiences may undermine deeper involvement with political content and detract from political engagement seem justified. A completely different picture emerges in the case of eudaimonic entertainment experiences that are driven by truthand meaning-seeking motivations and can stimulate processes of cognitive elaboration, information seeking and conversations about social and political issues (Schneider, 2012). Such outcomes are in line with normative ideals of informed citizenship and political deliberation (Habermas, 1984, 1985; Schütz, 1946; Weinmann \& Vorderer, 2018). Thus, they seem to provide a promising avenue for research into potential positive effects of political entertainment.

\section{Toward an Extended Dual-Process Model of Entertainment Effects on Political Information Processing and Engagement}

To fully harness the potential of dual-process models of entertainment for political communication, the current state of theorizing needs to be extended to incorporate different types of politically relevant outcomes. Therefore, in the following sections, we provide a 
systematic review of politically relevant outcome variables and their relationship with hedonic and eudaimonic entertainment and associated modes of cognitive processing. Figure 1 gives an overview of the extended dual-process model of entertainment effects on political information processing and engagement, the details of which are explained below.

[Fig. 1 here]

\section{Effects of Heuristic Processing of Entertainment Media}

With regard to hedonic entertainment and heuristic processing, the model draws on the extensive research literature on implicit media effects. It includes concepts such as cultivation (Gerbner et al., 2002) and narrative persuasion (Green \& Brock, 2002), which were developed to explain implicit learning and persuasion effects of entertainment media. In addition, concepts such as fictional framing, priming, and agenda setting (e.g., Holbert et al., 2003; Holbrook \& Hill, 2005; Mulligan \& Habel, 2011) are taken into account, which were originally developed in the field of political communication and subsequently transferred to entertainment media. Common to all of these approaches is a heuristic mode of processing in which information, attitudes, and stereotypes are transferred from media portrayals to perceived social reality, for example, through associative learning and heuristics (for an overview, see e.g., Taber \& Young, 2013). In line with the theoretical and empirical state of research, the model assumes that heuristic processing can lead to immediate, unreflective, and relatively short-term media effects. The following concepts are relevant in this context.

Cultivation. Cultivation effects describe the influence of entertaining media content on viewers' perceptions of social reality (Gerbner et al., 2002; Shrum, 2002). According to the cultivation hypothesis, heavy viewers orient themselves more strongly towards the representations of social reality presented on television than light viewers. Consequently, heavy viewers' worldviews are more biased. Such a bias can result from both the perception of reality (e.g., estimates and probabilities of crime rates) as well as attitudes, beliefs, and 
values (e.g., distrust of foreigners), which have been termed first-order and second-order cultivation effects, respectively (e.g., Shrum, 2002).

Exemplification. Another relevant phenomenon is the effect of exemplars (Zillmann \& Brosius, 2000). According to exemplification theory, the description of individual cases influences media users' perceptions and judgments of reality more strongly than base rate information, due to its greater vividness and cognitive availability.

Narrative Persuasion. Narrative persuasion focuses on the persuasive effects of fictional media content (Appel, 2008; Green \& Brock, 2002). Factors such as absorption by the story and identification with the characters play a key role in attitudinal and behavioral change (Slater \& Rouner, 2002).

Fictional Agenda Setting. Originally developed in the field of political news exposure, the agenda setting function of the media (McCombs \& Reynolds, 2002) can also be applied to fictional entertainment content. The frequency, consistency, and scope of political issues in fictional entertainment media can influence what media users think about and thus contribute to the perceived relevance of political issues (Holbrook \& Hill, 2005).

Fictional Priming. In a similar vein, media can also influence the cognitive availability of politically relevant evaluation criteria. Again, borrowing from political communication research (Iyengar, Peters, \& Kinder, 1982), priming effects have been investigated in entertainment media (Holbrook \& Hill, 2005). For instance, the political entertainment TV show The West Wing portrayed a fictional president, thereby providing clues for the evaluation of the actual US presidency and the real incumbent (Holbert et al., 2003).

Fictional Framing. Like news content, fictional formats also make use of certain frames of interpretation that highlight specific aspects of a topic as particularly relevant. 
Again, results showed that viewers adopt the frames of interpretation suggested by fictional portrayals and use them for their personal evaluation of the topic (Mulligan \& Habel, 2011).

All of the theoretical constructs discussed so far have in common that entertainment media are assumed to be processed in a heuristic mode that favors an unreflective transfer of information and attitudes from fictional media content to individuals' perception of social reality. This results in implicit media effects on knowledge, attitudes and behavior on an associative level, without conscious evaluation and decision-making processes.

\section{Effects of Elaborate Processing of Entertainment Media}

Compared to this research tradition on implicit effects of entertainment media, research on elaborate processing of entertainment media is only beginning to emerge. In the following section, we give an overview of political outcome variables that are relevant with regard to the elaborate mode of processing associated with eudaimonic entertainment experiences.

Information seeking. Initial research findings (Bartsch \& Schneider, 2014) show that eudaimonic entertainment can not only promote elaborate processing of media content, but can also stimulate further information seeking. Two experiments were conducted to examine how long, after watching a film scene or TV magazine on a politically relevant topic, participants spent reading hard-news articles on this topic, and how interesting they found the hard-news articles. Reading time and interest ratings were positively influenced by eudaimonic entertainment factors including negative valence, moderate arousal, and feeling moved by the entertainment stimulus (Bartsch \& Schneider, 2014). This indicates that eudaimonic entertainment factors can have an impact on subsequent media use including traditional news media. The model assumes that information seeking can mediate effects of eudaimonic entertainment on a cluster of other relevant outcome variables, because information seeking promotes the acquisition and encoding of additional relevant information 
from news and information media that goes beyond the information contained in the entertainment stimulus. In addition to its mediating role for other effects, information seeking can also be considered as an outcome variable in its own right, because the participation of citizens in public discourse constitutes a normatively desirable outcome.

A key construct related to information seeking is selective attention, which can be understood as a behavioral indicator for how motivated users are to seek further information about a topic they encountered in entertainment media. According to the selective exposure paradigm (Knobloch-Westerwick, 2015; Zillmann \& Bryant, 1985), selective attention is operationalized in terms of individuals' choices among a broader range of media content. Another behavioral indicator for information seeking is how much time users spend reading or viewing thematically related media content (duration of use). This has already been operationalized and linked to eudaimonic entertainment factors (Bartsch \& Schneider, 2014). In addition to behavioral indicators, users can rate their topic interest, thus providing an introspective assessment of their motivation for further information seeking (Bartsch \& Schneider, 2014).

Interpersonal communication. Another important mediating factor in the extended model is the interpersonal communication about topics encountered through eudaimonic entertainment experiences. After watching an emotionally moving film, viewers often feel the need to talk with others about the content (Bartsch, 2012b). Research on individuals' conversations about news content (Hefner, 2012) has shown that interpersonal communication and deliberation can mediate effects on knowledge acquisition and opinion formation. Hence, similar mediation effects on knowledge and opinions can be expected in the case of interpersonal communication and deliberation processes evoked by eudaimonic entertainment experiences. In addition to its potential mediating role for other effects, individuals' active participation in interpersonal deliberation can again be considered as a 
normatively desirable outcome in its own right. Hence, the extended model includes interpersonal communication processes that may begin during joint exposure to entertainment media, and may continue in everyday conversations that explore controversial issues and link the topic to personal experiences and background knowledge (e.g., Kim, Wyatt, \& Katz, 1999; Landreville, Holbert, \& LaMarre, 2010; Moy, Xenos, \& Hess, 2005; Sommer, 2013). Interpersonal communication about political topics in entertainment media can also take place via instant messengers or social network sites, the growing importance of which has been documented in research on social media use and second screening in political communication (e.g., Giglietto \& Selva, 2014; Gil de Zúñiga, Garcia-Perdomo, \& McGregor, 2015; Lochrie \& Coulton, 2011) .

In addition to the mediating factors, information seeking and interpersonal communication, the extended model includes three clusters of politically relevant outcome variables that correspond to the active, elaborate, and open-ended nature of eudaimonic truthand meaning-seeking: knowledge acquisition, elaborated opinion formation, and political participation.

Knowledge acquisition. Knowledge is a multi-faceted construct. With regard to entertainment media, it is important to distinguish at least two ways of knowledge acquisition. On the one hand, knowledge can be directly derived from entertainment media (see Wang \& Singhal, this volume). On the other hand, entertainment can raise issue interest and motivate processes of interpersonal communication and information seeking, which then result in further knowledge acquisition about the issue. Another important distinction concerns objective and subjective knowledge (Alba \& Hutchinson, 2000). Issue-related knowledge acquisition, assessed via standardized items (e.g., Baum, 2003; Delli Carpini \& Keeter, 1996) or via recognition or cued recall (Lang et al., 2013), indicates how information is encoded and stored. From a subjective perspective, the perceived gain in knowledge can 
gratify individuals' need for information (e.g., Roth et al., 2014; Schneider, Bartsch, \& Gleich, 2015; Schneider, Weinmann, Roth, Knop, \& Vorderer, 2016), which may provide an additional motivating factor for further information seeking and use (e.g., Schmitt, Schneider, Weinmann, \& Roth, 2019).

Political Participation. Another cluster includes political participation processes that can be stimulated by eudaimonic entertainment experiences. Several studies indicate that emotional involvement, elaborate processing, and information seeking are part of a cluster of politically activating effects, which also includes participatory intentions (e.g., Brader, 2005; Marcus, Neuman, \& MacKuen, 2000; Obermaier, Haim, \& Reinemann, 2014; Sotirovic \& McLeod, 2001; Valentino, Brader, Groenendyk, Gregorowicz, \& Hutchings, 2011). So far, entertainment has mostly been associated with negative effects on political participation (e.g., Butler, Koopman, \& Zimbardo, 1995; Putnam, 2000; Sotirovic \& McLeod, 2001). However, a more nuanced picture emerged in a study by Shah (1998) who found negative as well as positive effects of entertainment on political participation depending on entertainment genres. TV use in general and specific genres such as science fiction (which may be categorized as hedonic entertainment) were negatively related to civic engagement, whereas the genre of social drama (a typical eudaimonic genre; Oliver \& Bartsch, 2010; Oliver \& Raney, 2011) was positively associated with participation. Moreover, research on the role of emotional involvement in political communication (e.g., Brader, 2005; Obermaier et al., 2014; Valentino et al., 2011; Valentino, Gregorowicz, \& Groenendyk, 2009) has shown that emotions elicited by media content can reinforce different forms of political participationincluding conventional and nonconventional political participation, civic participation, and civic engagement (Barrett \& Brunton-Smith, 2014).

From the perspective of participatory liberal theory of the public sphere (cf. Ferree, Gamson, Gerhards, \& Rucht, 2002; Teorell, 2006), those forms which engage, empower, and 
mobilize citizens are particularly important for a strong democracy. From a deliberation viewpoint, the focus of participation lies more in expressing one's opinion and taking part in discussions (Ferree et al., 2002; Teorell, 2006). Accordingly, interpersonal communicationas outlined above — can be seen not only as a mediator of participation but also as a form of participation in itself. An emerging line of research suggests that such forms of discourseoriented participation frequently occur as a result of eudaimonic entertainment experiences (Bartsch, 2012b; Myrick \& Oliver, 2015).

Elaborated opinion formation. In contrast to implicit persuasion effects associated with hedonic entertainment (e.g., cultivation, narrative persuasion; see above), the final cluster of outcome variables associated with eudaimonic entertainment includes elaborated forms of opinion formation. In line with dual-process models of persuasion like the ELM (Petty \& Cacioppo, 1986) and similar approaches (Chen \& Chaiken, 1999; Forgas, 2002; Kahneman, 2003; Lang, 2006) our model assumes that opinions formed by thoughtful considerations of pros and cons are more enduring, resistant to change, and predictive of behavior. Elaborated opinion formation can either be based on information directly provided by entertainment media (as represented by the direct path in the model), or on information obtained in the process of interpersonal communication and information seeking (which are represented in the model as mediating factors).

According to the ELM, a basic prerequisite for elaborate opinion formation is the perceived personal relevance of the respective topic. In addition, however, eudaimonic entertainment has the potential to foster empathetic relevance through processes of perspective taking. In this case, empathy and concern for others' well-being can substitute personal relevance as the driver for an elaborate opinion formation (for an overview, see Bartsch \& Oliver, 2017). As a result, prejudices and stereotypes can be reduced and prosocial or altruistic behavioral intentions can be strengthened (Batson, Chang, Orr, \& Rowland, 
2002; Batson et al., 1997). Finally, entertainment content can also encourage opinion formation based on moral elaboration. For example, the portrayal of moral values such as care or fairness (Graham et al., 2013) can elicit moral emotions that are focused on others or the common good (e.g., admiration, compassion), and in turn increase the motivation for moral behavior (Algoe \& Haidt, 2009; Aquino, McFerran, \& Laven, 2011; Haidt, 2003; Oliver, Hartmann, \& Woolley, 2012).

\section{Conclusion and Outlook}

The extended dual-process model of entertainment effects on political information processing and engagement developed in this chapter highlights the potential of eudaimonic entertainment experiences in promoting a number of politically relevant outcomes characterized by active and reflective processing of political issues. Thus, the model complements previous research on passive and unreflective persuasion effects that result from heuristic processing — as described by theories of cultivation (Gerbner et al., 2002; Shrum, 2002), exemplification (Zillmann \& Brosius, 2000), narrative persuasion (Appel, 2008; Green \& Brock, 2002), and fictional framing, priming and agenda setting (Holbert et al., 2003; Holbrook \& Hill, 2005; Mulligan \& Habel, 2011). In line with other dual-process models, elaborate and heuristic processing are not seen as mutually exclusive. Heuristic processing is part of eudaimonic entertainment experiences as well, but its results can become the subject of deeper reflection and reevaluation through elaborate processing.

The added value of elaboration processes associated with eudaimonic entertainment, and related outcomes such as information seeking, interpersonal communication, elaborated opinion formation, knowledge acquisition, and political participation have not been systematically incorporated in research on entertainment and political communication so far. Our theoretical framework offers a differentiated perspective on hedonic and eudaimonic entertainment experiences and associated outcomes. Despite legitimate concerns that certain 
forms of hedonic entertainment can undermine active, informed citizenship, it seems that other, eudaimonic forms of entertainment experience can promote normatively desirable outcomes from a deliberation and informed citizen perspective (Habermas, 1984, 1985; Schütz, 1946), and can serve a "vigorous democratic public life" (Ferree et al., 2002, p. 289). An interesting example of a media format that can promote eudaimonic experiences by combining the advantages of entertainment and information programs can be found in socalled television theme nights (a concept increasingly popular in Germany). Theme nights present entertainment and information programs in tandem, with the aim of (1) stimulating audience interest through fictional entertainment programs that promote empathy and emotional involvement with the issue, and (2) presenting audiences with an information program that provides factual information about the issue. This form of entertaining political communication combines the respective strengths of fictional entertainment and fact-based information without intermixing them, thus providing an alternative to widely criticized hybrid formats such as soft news, infotainment or politainment. Preliminary evidence (Angerer \& Bartsch, 2018) suggests that audience members who saw a moving feature film prior to a documentary on the same issue reported higher levels of issue interest and prosocial responses mediated by eudaimonic experiences (feeling moved and cognitive elaboration). Further hypotheses derived from the extended dual-process model of entertainment effects on political information processing and engagement presented in this chapter await empirical scrutiny with regard to TV theme nights (and similar formats that present entertainment and information in tandem, for example on online platforms). In particular, more research is needed concerning other politically relevant outcomes beyond issue interest including knowledge acquisition and political participation as well as mediating factors such as coviewing, interpersonal communication and active information seeking beyond the informational program presented as part of the theme night. 
On a more general note, to better understand and harness the positive potentials of entertainment media in political discourse, the conditions under which entertainment media can elicit active and reflective forms of processing are an important object of future research. Although some of the causal relationships in the model have been supported by experimental research (Bartsch \& Schneider, 2014), the evidence for other paths is only correlational, or lacking at all. Thus, taken together, the current state of research is rather fragmentary, but we hope that the extended dual-process model of entertainment effects on political information processing and engagement will help to organize and address open research questions at the intersection of entertainment and political communication. 


\section{References}

Alba, J. W., \& Hutchinson, J. W. (2000). Knowledge calibration: What consumers know and what they think they know. Journal of Consumer Research, 27, 123-156. https://doi.org/10.1086/314317

Algoe, S. B., \& Haidt, J. (2009). Witnessing excellence in action: the 'other-praising' emotions of elevation, gratitude, and admiration. Journal of Positive Psychology, 4, 105-127. https://doi.org/10.1080/17439760802650519

Andersen, K. (2019). An entrance for the uninterested: Who watches soft news and how does it affect their political participation? Mass Communication and Society, 22, 487-507. https://doi.org/10.1080/15205436.2019.1585544

Angerer, L., \& Bartsch, A. (2018, May). Show me, don't tell me. Synergy effects of entertainment and information programs about organ donation. Paper presentation at the 68th Annual Conference of the International Communication Association (ICA). Prague, Czech Republic.

Appel, M. (2008). Fictional narratives cultivate just-world beliefs. Journal of Communication, 58, 62-83. https://doi.org/10.1111/j.1460-2466.2007.00374.x

Aquino, K., McFerran, B., \& Laven, M. (2011). Moral identity and the experience of moral elevation in response to acts of uncommon goodness. Journal of Personality and Social Psychology, 100, 703-718. https://doi.org/10.1037/a0022540

Aristotle. (trans. 2002). Nicomachean ethics. (Rowe, C., \& Broadie, S., Eds.). Oxford, UK: Oxford University Press.

Barrett, M., \& Brunton-Smith, I. (2014). Political and civic engagement and participation: Towards an integrative perspective. Journal of Civil Society, 10, 5-28. https://doi.org/10.1080/17448689.2013.871911 
Bartsch, A. (2012a). As time goes by: What changes and what remains the same in entertainment experience over the life span? Journal of Communication, 62, 588-608. https://doi.org/10.1111/j.1460-2466.2012.01657.x

Bartsch, A. (2012b). Emotional gratification in entertainment experience. Why viewers of movies and television series find it rewarding to experience emotions. Media Psychology, 15, 267-302. https://doi.org/10.1080/15213269.2012.693811

Bartsch, A., \& Hartmann, T. (2017). The role of cognitive and affective challenge in entertainment experience. Communication Research, 44, 29-53. https://doi.org/10.1177/0093650214565921

Bartsch, A., Kalch, A., \& Oliver, M. B. (2014). Moved to think: The role of emotional media experiences in stimulating reflective thoughts. Journal of Media Psychology, 26, 125140. https://doi.org/10.1027/1864-1105/a000118

Bartsch, A., \& Oliver, M. B. (2011). Making sense of entertainment: On the interplay of emotion and cognition in entertainment experience. Journal of Media Psychology, 23, 12-17. https://doi.org/10.1027/1864-1105/a000026

Bartsch, A., \& Oliver, M. B. (2017). Appreciation of meaningful entertainment experiences and eudaimonic well-being. In L. Reinecke \& M. B. Oliver (Eds.), The Routledge handbook of media use and well-being (pp. 80-92). New York, NY: Routledge.

Bartsch, A., \& Schneider, F. M. (2014). Entertainment and politics revisited: How nonescapist forms of entertainment can stimulate political interest and information seeking. Journal of Communication, 64, 369-396. https://doi.org/10.1111/jcom.12095

Batson, C. D., Chang, J., Orr, R., \& Rowland, J. (2002). Empathy, attitudes, and action: Can feeling for a member of a stigmatized group motivate one to help the group? Personality and Social Psychology Bulletin, 28, 1656-1666. https://doi.org/10.1177/014616702237647 
Batson, C. D., Polycarpou, M. P., Harmon-Jones, E., Imhoff, H. J., Mitchener, E. C., Bednar, L. L., ...Highberger, L. (1997). Empathy and attitudes: Can feeling for a member of a stigmatized group improve feelings toward the group? Journal of Personality and Social Psychology, 72, 105-118. https://doi.org/10.1037/0022-3514.72.1.105

Baum, M. A. (2003). Soft news and political knowledge: Evidence of absence or absence of evidence? Political Communication, 20, 173-190. https://doi.org/10.1080/10584600390211181

Baum, M. A. (2005). Talking the vote: Why presidential candidates hit the talk show circuit. American Journal of Political Science, 49, 213-234. https://doi.org/10.1111/j.00925853.2005.t01-1-00119.x

Baum, M. A., \& Jamison, A. S. (2006). The Oprah effect: How soft news helps inattentive citizens vote consistently. The Journal of Politics, 68, 946-959. https://doi.org/10.1111/j.1468-2508.2006.00482.x

Boukes, M., \& Boomgaarden, H. G. (2015). Soft news with hard consequences? Introducing a nuanced measure of soft versus hard news exposure and its relationship with political cynicism. Communication Research, 42, 701-731. https://doi.org/10.1177/0093650214537520

Brader, T. (2005). Striking a responsive chord: How political ads motivate and persuade voters by appealing to emotions. American Journal of Political Science, 49, 388-405. https://doi.org/10.2307/3647684

Brants, K., \& Neijens, P. (1998). The infotainment of politics. Political Communication, 15, 149-164. https://doi.org/10.1080/10584609809342363

Butler, L. D., Koopman, C., \& Zimbardo, P. G. (1995). The psychological impact of viewing the film JFK: Emotions, beliefs, and political behavioral intentions. Political Psychology, 16, 237-257. https://doi.org/10.2307/3791831 
Cacioppo, J. T., Gardner, W. L., \& Berntson, G. G. (1999). The affect system has parallel and integrative processing components: Form follows function. Journal of Personality and Social Psychology, 76, 839-855. https://doi.org/10.1037/0022-3514.76.5.839

Chen, S., \& Chaiken, S. (1999). The heuristic-systematic model in its broader context. In S. Chaiken \& Y. Trope (Eds.), Dual-process theories in social psychology (pp. 73-96). New York, NY: Guilford Press.

Cupchik, G. C. (1995). Emotion in aesthetics: Reactive and reflective models. Poetics, 23, 177-188. https://doi.org/10.1016/0304-422X(94)00014-W

Cupchik, G. C., \& Laszlo, J. (1994). The landscape of time in literary reception: Character experience and narrative action. Cognition and Emotion, 8, 297-312. https://doi.org/10.1080/02699939408408943

Delli Carpini, M. X., \& Keeter, S. (1996). What Americans know about politics and why it matters. New Haven, CT: Yale University Press.

Donsbach, W., \& Büttner, K. (2005). Boulevardisierungstrend in deutschen Fernsehnachrichten: Darstellungsmerkmale der Politikberichterstattung vor den Bundestagswahlen 1983, 1990 und 1998 [Trends of tabloidization in German TV news: How the news broadcast presented politics before the general elections in 1983, 1990, and 1998]. Publizistik, 50, 21-38. https://doi.org/10.1007/s11616-005-0116-6

Esser, F. (1999). ‘Tabloidization' of news: A comparative analysis of Anglo-American and German press journalism. European Journal of Communication, 14, 291-324. https://doi.org/10.1177/0267323199014003001

Ferree, M. M., Gamson, W. A., Gerhards, J., \& Rucht, D. (2002). Four models of the public sphere in modern democracies. Theory and Society, 31, 289-324. https://doi.org/10.1023/A:1016284431021 
Forgas, J. P. (1995). Mood and judgment: The affect infusion model (AIM). Psychological Bulletin, 117, 39-66. https://doi.org/10.1037/0033-2909.117.1.39

Forgas, J. P. (2002). Feeling and doing: Affective influences on interpersonal behavior. Psychological Inquiry, 13, 1-28. https://doi.org/10.1207/S15327965PLI1301_01

Friedrich, K., \& Jandura, O. (2012). Politikvermittlung durch Boulevardjournalismus: Eine öffentlichkeitstheoretische Neubewertung [The communication of politics by tabloid journalism - A re-evaluation in terms of a theory of the public spheres]. Publizistik, 57, 403-417. https://doi.org/10.1007/s11616-012-0158-5

Gerbner, G., Gross, L., Morgan, M., Signorielli, N., \& Shanahan, J. (2002). Growing up with television: Cultivation processes. In J. Bryant \& D. Zillmann (Eds.), Media effects. Advances in theory and research (2nd ed., pp. 43-67). Mahwah, NJ: Erlbaum.

Giglietto, F., \& Selva, D. (2014). Second screen and participation: A content analysis on a full season dataset of tweets. Journal of Communication, 64, 260-277. https://doi.org/10.1111/jcom.12085

Gil de Zúñiga, H., Garcia-Perdomo, V., \& McGregor, S. C. (2015). What is second screening? Exploring motivations of second screen use and its effect on online political participation. Journal of Communication, 65, 793-815. https://doi.org/10.1111/jcom.12174

Graham, J., Haidt, J., Koleva, S., Motyl, M., Iyer, R., Wojcik, S. P., \& Ditto, P. H. (2013). Moral foundations theory: The pragmatic validity of moral pluralism. In P. Devine \& A. Plant (Eds.), Advances in experimental social psychology, Vol. 47 (pp. 55-130). San Diego, CA: Elsevier Academic Press.

Green, M. C., \& Brock, T. C. (2000). The role of transportation in the persuasiveness of public narratives. Journal of Personality and Social Psychology, 79, 701-721. https://doi.org/10.1037/0022-3514.79.5.701 
Green, M. C., \& Brock, T. C. (2002). In the mind's eye: Transportation-imagery model of narrative persuasion. In M. C. Green, J. J. Strange, \& T. C. Brock (Eds.), Narrative impact. Social and cognitive foundations (pp. 315-341). Mahwah, NJ: Erlbaum.

Guggenheim, L., Kwak, N., \& Campbell, S. W. (2011). Nontraditional news negativity: The relationship of entertaining political news use to political cynicism and mistrust. International Journal of Public Opinion Research, 23, 287-314. https://doi.org/10.1093/ijpor/edr015

Habermas, J. (1984). The theory of communicative action: Vol. 1. Reason and the rationalization of society. Boston, MA: Beacon.

Habermas, J. (1985). The theory of communicative action: Vol. 2. Lifeworld and system: A critique of functionalist reason. Boston, MA: Beacon.

Haidt, J. (2003). The moral emotions. In R. J. Davidson, K. R. Scherer, \& H. H. Goldsmith (Eds.), Handbook of affective sciences (pp. 852-870). New York, NY: Oxford University Press.

Hefner, D. (2012). Alltagsgespräche über Nachrichten: Medienrezeption, politische Expertise und die wissensbildende Qualität von Anschlusskommunikation [Talking about the news: Media reception, political expertise, and the knowledge building quality of subsequent discussions]. Baden-Baden: Nomos.

Holbert, R. L., Pillion, O., Tschida, D. A., Armfield, G. G., Kinder, K., Cherry, K. L., \& Daulton, A. R. (2003). The West Wing as endorsement of the U.S. presidency: Expanding the bounds of priming in political communication. Journal of Communication, 53, 427-443. https://doi.org/10.1111/j.1460-2466.2003.tb02600.x

Holbrook, R. A., \& Hill, T. G. (2005). Agenda-setting and priming in prime time television: Crime dramas as political cues. Political Communication, 22, 277-295. https://doi.org/10.1080/10584600591006519 
Iyengar, S., Peters, M. D., \& Kinder, D. R. (1982). Experimental demonstrations of the "notso-minimal" consequences of television news programs. American Political Science Review, 76, 848-858. https://doi.org/10.2307/1962976

Kahneman, D. (2003). A perspective on judgment and choice: Mapping bounded rationality. American Psychologist, 58, 697-720. https://doi.org/10.1037/0003-066X.58.9.697

Kim, J., Wyatt, R. O., \& Katz, E. (1999). News, talk, opinion, participation: The part played by conversation in deliberative democracy. Political Communication, 16, 361-385. https://doi.org/10.1080/105846099198541

Klimmt, C. (2011). Media psychology and complex modes of entertainment experiences. Journal of Media Psychology, 23, 34-38. https://doi.org/10.1027/1864-1105/a000030

Knobloch-Westerwick, S. (2006). Mood management: Theory, evidence, and advancements. In J. Bryant \& P. Vorderer (Eds.), Psychology of entertainment (pp. 239-254). Mahwah, NJ: Erlbaum.

Knobloch-Westerwick, S. (2015). Choice and preference in media use: Advances in selective exposure theory and research. New York, NY: Taylor \& Francis.

Landreville, K. D., Holbert, R. L., \& LaMarre, H. L. (2010). The influence of late-night TV comedy viewing on political talk: A moderated-mediation model. International Journal of Press/Politics, 15, 482-498. https://doi.org/10.1177/1940161210371506

Lang, A. (2006). Using the limited capacity model of motivated mediated message processing to design effective cancer communication messages. Journal of Communication, 56, S57-S80. https://doi.org/10.1111/j.1460-2466.2006.00283.x

Lang, A., Sanders-Jackson, A., Wang, Z., \& Rubenking, B. (2013). Motivated message processing: How motivational activation influences resource allocation, encoding, and storage of TV messages. Motivation and Emotion, 37, 508-517. https://doi.org/10.1007/s11031-012-9329-y 
Lewis, R. J., Tamborini, R., \& Weber, R. (2014). Testing a dual-process model of media enjoyment and appreciation. Journal of Communication, 64, 397-416. https://doi.org/10.1111/jcom.12101

Lochrie, M., \& Coulton, P. (2011). Mobile phones as second screen for TV, enabling interaudience interaction. In T. Romão, N. Correia, M. Inami, H. Kato, R. Prada, T. Terada, ... (Eds.), Proceedings of the 8th International Conference on Advances in Computer Entertainment Technology - ACE'11 (Article No. 73). New York, NY: ACM Press.

Marcus, G. E., Neuman, W. R., \& MacKuen, M. (2000). Affective intelligence and political judgment. Chicago, IL: University of Chicago Press.

McCombs, M., \& Reynolds, A. (2002). News influence on our pictures of the world. In J. Bryant \& D. Zillmann (Eds.), Media effects. Advances in theory and research (2nd ed., pp. 1-18). Mahwah, NJ: Erlbaum.

Moy, P., Xenos, M. A., \& Hess, V. K. (2005). Communication and citizenship: Mapping the political effects of infotainment. Mass Communication and Society, 8, 111-131. https://doi.org/10.1207/s15327825mcs0802_3

Moyer-Gusé, E. (2008). Toward a theory of entertainment persuasion: Explaining the persuasive effects of entertainment-education messages. Communication Theory, 18, 407-425. https://doi.org/10.1111/j.1468-2885.2008.00328.x

Mulligan, K., \& Habel, P. (2011). An experimental test of the effects of fictional framing on attitudes. Social Science Quarterly, 92, 79-99. https://doi.org/10.1111/j.15406237.2011.00758.x

Myrick, J. G., \& Oliver, M. B. (2015). Laughing and crying: mixed emotions, compassion, and the effectiveness of a YouTube PSA about skin cancer. Health Communication, 30, 820-829. https://doi.org/10.1080/10410236.2013.845729 
Obermaier, M., Haim, M., \& Reinemann, C. (2014). Emotionen bewegen? Ein Experiment zur Wirkung von Medienbeiträgen mit Emotionalisierungspotenzial auf Emotionen, politische Partizipationsabsichten und weiterführende Informationssuche. $M \& K$ Medien \& Kommunikationswissenschaft, 62, 216-235. https://doi.org/10.5771/1615$634 x-2014-2-216$

Oliver, M. B. (2008). Tender affective states as predictors of entertainment preference. Journal of Communication, 58, 40-61. https://doi.org/10.1111/j.14602466.2007.00373.x

Oliver, M. B., \& Bartsch, A. (2010). Appreciation as audience response: Exploring entertainment gratifications beyond hedonism. Human Communication Research, 36, 53-81. https://doi.org/10.1111/j.1468-2958.2009.01368.x

Oliver, M. B., \& Hartmann, T. (2010). Exploring the role of meaningful experiences in users' appreciation of "good movies". Projections: The Journal of Movies and Mind, 4, 128150. https://doi.org/10.3167/proj.2010.040208

Oliver, M. B., Hartmann, T., \& Woolley, J. K. (2012). Elevation in response to entertainment portrayals of moral virtue. Human Communication Research, 38, 360-378. https://doi.org/10.1111/j.1468-2958.2012.01427.x

Oliver, M. B., \& Raney, A. A. (2011). Entertainment as pleasurable and meaningful: Identifying hedonic and eudaimonic motivations for entertainment consumption. Journal of Communication, 61, 984-1004. https://doi.org/10.1111/j.14602466.2011.01585.x

Oliver, M. B., Raney, A. A., Slater, M. D., Appel, M., Hartmann, T., Bartsch, A., ...Das, E. (2018). Self-transcendent media experiences: Taking meaningful media to a higher level. Journal of Communication, 68, 380-389. https://doi.org/10.1093/joc/jqx020 
Otto, L., Glogger, I., \& Boukes, M. (2017). The softening of journalistic political communication-A critical review of sensationalism, soft news, infotainment, and tabloidization and a comprehensive framework model. Communication Theory, 27, 136-155. https://doi.org/10.1111/comt.12102

Petty, R. E., \& Cacioppo, J. T. (1986). Communication and persuasion: Central and peripheral routes to attitude change. New York, NY: Springer.

Postman, N. (1986). Amusing ourselves to death: Public discourse in the age of show business (4. print). New York, NY: Viking Penguin.

Prior, M. (2003). Any good news in soft news? The impact of soft news preference on political knowledge. Political Communication, 20, 149-171. https://doi.org/10.1080/10584600390211172

Putnam, R. D. (2000). Bowling alone: The collapse and revival of American community. New York, NY: Simon \& Schuster.

Reinemann, C., Stanyer, J., Scherr, S., \& Legnante, G. (2012). Hard and soft news: A review of concepts, operationalizations and key findings. Journalism, 13, 221-239. https://doi.org/10.1177/1464884911427803

Roth, F. S., Weinmann, C., Schneider, F. M., Hopp, F., \& Vorderer, P. (2014). Seriously entertained: Antecedents and consequences of hedonic and eudaimonic entertainment experiences with political talk shows on TV. Mass Communication and Society, 17, 379-399. https://doi.org/10.1080/15205436.2014.891135

Schmitt, J. B., Schneider, F. M., Weinmann, C., \& Roth, F. S. (2019). Saving Tiger, Orangutan \& Co: how subjective knowledge and text complexity influence online information seeking and behavior. Information, Communication \& Society, 22, 11931211. https://doi.org/10.1080/1369118X.2017.1410206 
Schneider, F. M. (2012). Measuring subjective movie evaluation criteria. Conceptual foundation, construction, and validation of the SMEC scales (Dissertation). Universität Koblenz-Landau. Landau. Retrieved from http://nbnresolving.de/urn:nbn:de:hbz:lan1-7813

Schneider, F. M., Bartsch, A., \& Gleich, U. (2015). Spaß, Spannung...Denkanstöße? Hedonische und eudaimonische Gratifikationen, Bewertungen und Folgen der Rezeption von Stefan Raabs Sendung „Absolute Mehrheit“ [Fun, suspense...food for thought? Hedonic and eudaimonic gratifications, evaluations, and outcomes of watching Stefan Raab's talk show „Absolute Mehrheit”]. SC|M: Studies in Communication | Media, 4, 53-68. https://doi.org/10.5771/2192-4007-2015-1-53

Schneider, F. M., Weinmann, C., Roth, F. S., Knop, K., \& Vorderer, P. (2016). Learning from entertaining online video clips? Enjoyment and appreciation and their differential relationships with knowledge and behavioral intentions. Computers in Human Behavior, 54, 475-482. https://doi.org/10.1016/j.chb.2015.08.028

Schramm, H., \& Wirth, W. (2008). A case for an integrative view on affect regulation through media usage. Communications: The European Journal of Communication Research, 33, 27-46. https://doi.org/10.1515/COMMUN.2008.002

Schütz, A. (1946). The well-informed citizen: An essay on the social distribution of knowledge. Social Research, 13, 463-478.

Schwarz, N., \& Clore, G. L. (2003). Mood as information: 20 years later. Psychological Inquiry, 14, 296-303. https://doi.org/10.1080/1047840X.2003.9682896

Shah, D. V. (1998). Civic engagement, interpersonal trust, and television use: An individuallevel assessment of social capital. Political Psychology, 19, 469-496. https://doi.org/10.1111/0162-895X.00114 
Shrum, L. J. (2002). Media consumption and perceptions of social reality: Effects and underlying processes. In J. Bryant \& D. Zillmann (Eds.), Media effects. Advances in theory and research (2nd ed., pp. 69-95). Mahwah, NJ: Erlbaum.

Slater, M. D., \& Rouner, D. (2002). Entertainment-education and elaboration likelihood: Understanding the processing of narrative persuasion. Communication Theory, 12, 173-191. https://doi.org/10.1093/ct/12.2.173

Sommer, D. (2013). Nachrichten im Gespräch: Wesen und Wirkung von Anschlusskommunikation über Fernsehnachrichten. Baden-Baden: Nomos.

Sotirovic, M., \& McLeod, J. M. (2001). Values, communication behavior, and political participation. Political Communication, 18, 273-300. https://doi.org/10.1080/10584600152400347

Sparks, C., \& Tulloch, J. (Eds.). (2000). Tabloid tales: Global debates over media standards. Lanham, MD: Rowman \& Littlefield.

Taber, C. S., \& Young, E. (2013). Political information processing. In L. Huddy, D. O. Sears, \& J. S. Levy (Eds.), The Oxford handbook of political psychology (2nd ed., pp. 525558). New York, NY: Oxford University Press.

Tamborini, R., Bowman, N. D., Eden, A., Grizzard, M., \& Organ, A. (2010). Defining media enjoyment as the satisfaction of intrinsic needs. Journal of Communication, 60, 758777. https://doi.org/10.1111/j.1460-2466.2010.01513.x

Teorell, J. (2006). Political participation and three theories of democracy: A research inventory and agenda. European Journal of Political Research, 45, 787-810. https://doi.org/10.1111/j.1475-6765.2006.00636.x

Umbricht, A., \& Esser, F. (2016). The push to popularize politics: Understanding the audience-friendly packaging of political news in six media systems since the 1960s. Journalism Studies, 17, 100-121. https://doi.org/10.1080/1461670X.2014.963369 
Valentino, N. A., Beckmann, M. N., \& Buhr, T. A. (2001). A spiral of cynicism for some: The contingent effects of campaign news frames on participation and confidence in government. Political Communication, 18, 347-367. https://doi.org/10.1080/10584600152647083

Valentino, N. A., Brader, T., Groenendyk, E. W., Gregorowicz, K., \& Hutchings, V. L. (2011). Election night's alright for fighting: The role of emotions in political participation. Journal of Politics, 73, 156-170. https://doi.org/10.1017/S0022381610000939

Valentino, N. A., Gregorowicz, K., \& Groenendyk, E. W. (2009). Efficacy, emotions and the habit of participation. Political Behavior, 31, 307-330. https://doi.org/10.1007/s11109-008-9076-7

Vorderer, P., Klimmt, C., \& Ritterfeld, U. (2004). Enjoyment: At the heart of media entertainment. Communication Theory, 14, 388-408. https://doi.org/10.1111/j.14682885.2004.tb00321.x

Vorderer, P., \& Reinecke, L. (2012). Zwei-Prozess-Modelle des Unterhaltungserlebens: Unterhaltung im Schnittbereich hedonischer und non-hedonischer Bedürfnisbefriedigung [Two-process models of entertainment experience: Entertainment in the intersection between hedonic and nonhedonic need satisfaction]. In L. Reinecke \& S. Trepte (Eds.), Unterhaltung in neuen Medien. Perspektiven zur Rezeption und Wirkung von Online-Medien und interaktiven Unterhaltungsformaten [Entertainment in the new media. Perspectives of the reception and effects of online media and interactive entertainment formats] (pp. 12-29). Köln: von Halem.

Vorderer, P., \& Ritterfeld, U. (2009). Digital games. In R. L. Nabi \& M. B. Oliver (Eds.), The Sage handbook of media processes and effects (pp. 455-467). Thousand Oaks, CA: Sage. 
Weinmann, C., \& Vorderer, P. (2018). A normative perspective for political entertainment research: Connecting deliberative democracy and entertainment theory. Communication Theory, 28, 466-486. https://doi.org/10.1093/ct/qty018

Wirth, W., Hofer, M., \& Schramm, H. (2012). Beyond pleasure: Exploring the eudaimonic entertainment experience. Human Communication Research, 38, 406-428. https://doi.org/10.1111/j.1468-2958.2012.01434.x

Zillmann, D. (1988). Mood management: Using entertainment to full advantage. In L. Donohew, H. E. Sypher, \& E. T. Higgins (Eds.), Communication, social cognition, and affect (pp. 147-171). Hillsdale, NJ: Erlbaum.

Zillmann, D., \& Brosius, H.-B. (2000). Exemplification in communication: The influence of case reports on the perception of issues. Mahwah, NJ: Erlbaum.

Zillmann, D., \& Bryant, J. (Eds.). (1985). Selective exposure to communication. Mahwah, N.J: Erlbaum. 


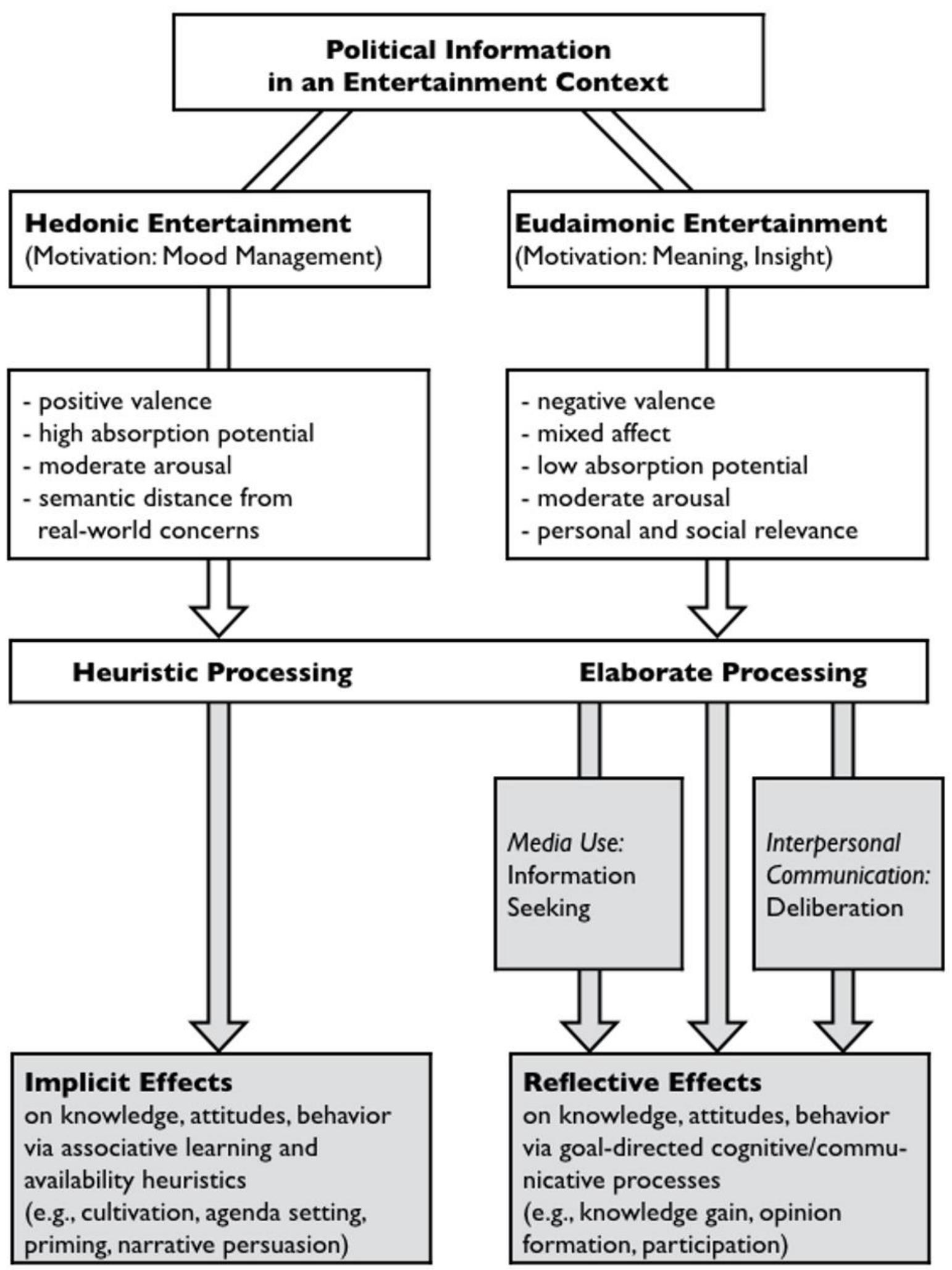

Figure 1. Extended dual-process model of entertainment effects on political information processing and engagement (with extended theoretical elements highlighted) 